\title{
Joint magnetic and gravity modelling of the Canoas Anomaly, southern Brazil
}

Louro, V.H.A. ${ }^{1}$, Negrão, A.P. ${ }^{1}$, Castro, L.G. ${ }^{2}$, Ferreira, F.J.F. ${ }^{2}$

${ }^{1}$ Universidade de São Paulo, ${ }^{2}$ Universidade Federal do Paraná
Copyright 2019, SBGf - Sociedade Brasileira de Geofísica

This paper was prepared for presentation during the $16^{\text {th }}$ International Congress of the Brazilian Geophysical Society held in Rio de Janeiro, Brazil, 19-22 August 2019.

Contents of this paper were reviewed by the Technical Committee of the $16^{\text {th }}$ International Congress of the Brazilian Geophysical Society and do not necessarily represent any position of the SBGf, its officers or members. Electronic reproduction o storage of any part of this paper for commercial purposes without the written consent of the Brazilian Geophysical Society is prohibited.

\section{Abstract}

This report presents a geophysical anomaly in the seaside of Paraná state, Brazil. The Canoas anomaly does not display outcropping evidences, nor have drillholes within its area. We used magnetic and gravity data to investigate and propose a geophysical model to explain this anomaly. The source of the anomaly indicated an approximately $5.5 \mathrm{~km}$ body elongated on the direction of the Ponta Grossa Arch (PGA), with its shallower portion varying from 20 to $200 \mathrm{~m}$, increasing towards the borders. The inversion resulted on a body analogue with mapped alkaline complexes, cut by highly magnetized subvertical dykes. We interpreted this scenario as an alkaline body of age like the Juquiá/Morro do Serrote alkaline center, intruded slightly to coeval with the PGA mafic dykes. New uncovered alkaline centers such as the source of Canoas anomaly may represent new reserves for phosphate and REE exploration in the long-term.

\section{Introduction}

Alkaline complexes in the borders of the Paraná Basin are prime sources for phosphates and niobium exploration in south Brazil. Many of these complexes are found in the Ponta Grossa Arch (PGA), and were geologically, geochemically and/or geophysically studied so far. The Juquiá (Born, 1971; Slavec et al., 2001), Ipanema (Rugenski et al. 2006), Jacupiranga (AlvaValdivia and López-Loera, 2011), and Tunas (Siga Júnior et al., 2007) are examples of the scientific effort over the alkaline complexes in the PGA. They present tectonic control that caused a pervasive faulting and magmatism subparallel to the arc axis (Gomes et al., 2011).

Dozens of alkaline centers can be found along the PGA lineaments (Gomes et al, 2011), however considerably less frequent between them (Fig. 1). Diabase and basaltic dykes related to the tholeiitic magmatism of the Serra Geral Formation (Riccomini et al., 2005) are spread all over the PGA as NW-SE-oriented dyke swarms.

Between the São Jerônimo-Curiúva and Rio Alonzo lineaments of the PGA, about $100 \mathrm{~km}$ to the southwest of the major concentration of alkaline complexes of São Jerônimo-Curiúva lineament, and below the Canoas beach, lies a geophysical anomaly (Ferreira et al., 2018). This area was covered with airborne magnetic and gamma-ray surveys performed during 2010 (CPRM,
2011), summed up to ground gravity and magnetic data collections. During the ground surveys, it could not be found evidences of geological expression outcropping in the area (Castro et al., 2008).

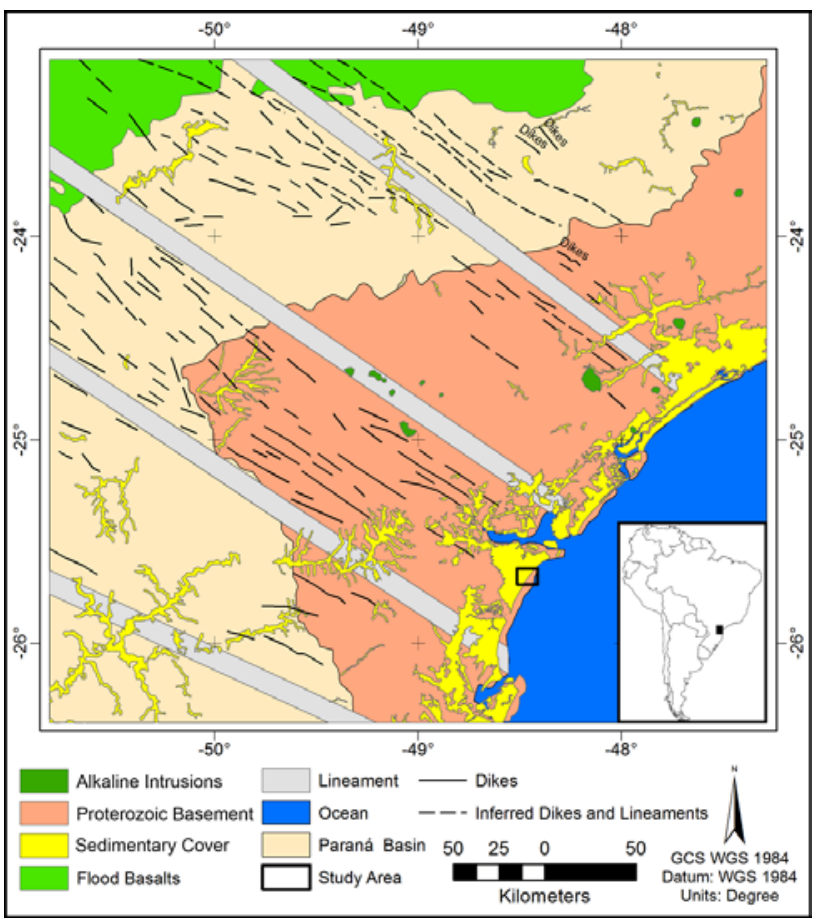

Figure 1 - Regional geology map of the PGA (modified from Riccomini et al., 2005). The dashed box represents the area of the geophysical anomaly in Fig. 4.

We analyzed and modelled the geophysical anomaly of Canoas beach using airborne magnetic and ground magnetic and gravity field data. The results were used to suggest the nature of the source of the anomaly, whether it is an alkaline intrusion, or a set of dykes commonly found in the area.

\section{Geology}

The PGA is an early Cretaceous NW-SE structural flexure-related arch in southern Brazil. It is characterized by a 20 to $60 \mathrm{~km}$ wide regional uplift active since the Paleozoic, plunging from the Atlantic Ocean towards to the center of the Paraná Basin for more than $600 \mathrm{~km}$ (Almeida, 1983; Riccomini et al., 2005; Fig. 1). Raposo (1995) suggests that the intense Serra Geral formation volcanic activity caused the uplift and reactivation of the arc. This process resulted in the placement of tholeiitic dyke swarms and alkaline complexes along four NW-SE subparallel lineaments, Guapiara, São Jerônimo-Curiúva, Rio Alonzo and Rio Piqueri, from north to south (Almeida, 1983). The Ponta Grossa Arc Province (Riccomini et al., 2005 ) is marked by alkaline rocks with mafic to ultramafic 
character, frequently presenting carbonatites and, in exceptional cases, felsic rocks as the Tunas intrusion.

The regional tholeiitic dyke swarm counts with hundreds of NW-oriented dykes of thicknesses varying from few centimeters to hundreds of meters (Raposo, 1995). The swarm is hosted by the Precambrian crystalline basement and sedimentary formations older than the Serra Geral magmatism. The dykes are mostly made of high- $\mathrm{TiO}_{2}$ basalts, with few intermediary rocks and rare acid occurrences (Marques and Ernesto, 2004).

The PGA displays a wide range of lithologies, from cumulate rocks to very evolved syenites, phonolites and associated carbonatites (Ruberti et al., 2005). In the northeasternmost bodies, e.g. Juquiá and Jacupiranga, predomine dunites and/or clinopyroxenites, with recurrent evidences of fractional crystallization processes (Beccaluva et al., 1992). The Cananéia intrusion and the minor intrusions of the alkaline center at the São Jerônimo-Curiúva Lineament, are mostly composed by peralkaline phonolites (Ruberti et al., 2005).

The area of Canoas beach is covered by sands and mudstones in alluvial and coastal alluvial deposits (Fig. $2 a)$. No outcrops of possible dykes or alkaline bodies could be found during the ground survey (Castro et al., 2008). Lessa et al. (2000) present data from drillholes to the south of Canoas anomaly. The drillholes reached depths from $70 \mathrm{~m}$ to $100 \mathrm{~m}$, where the granulitic basement was found. Sand and mud intercalations from 5 $\mathrm{m}$ to $20 \mathrm{~m}$ compound most of the lithologies, whereas gravel appeared in the Drillhole 7 at approximately $95 \mathrm{~m}$ (Fig. 2b).

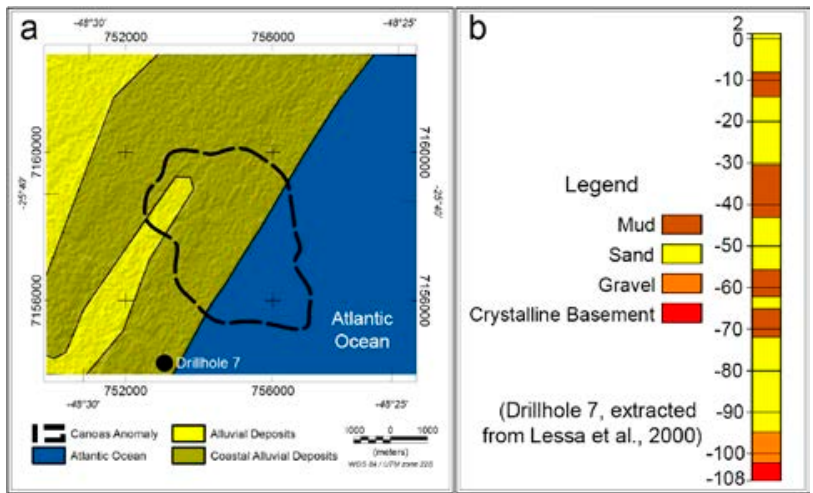

Figure 2 - (a) Local geology over the hillshaded digital elevation model; (b) Drillhole 7 description (extracted from Lessa et al., 2000).

\section{Data}

The area was covered using airborne magnetic and gamma-ray surveys (CPRM, 2011), and ground gravity and magnetic (Castro et al., 2008). The airborne data was collected and processed by LASA Prospecções S/A from 2009 to 2010 . The survey lines were spaced by $500 \mathrm{~m}$ in north-south direction whereas the tie lines were $10000 \mathrm{~m}$ apart in east-west direction. The nominal terrain clearance was $100 \mathrm{~m}$ at an airspeed of approximately 280 $\mathrm{km} / \mathrm{h}$. The ground magnetic and gravity survey was performed along an approximately $65 \mathrm{~km}$ northeastsouthwest profile following the shoreline. The magnetic and gravity stations were measured at c.a. 25 and $500 \mathrm{~m}$ intervals, respectively.

\section{Results and Discussion}

The two geological features causing potential field anomalies in the PGA are mafic dyke swarms and alkaline complexes. Magnetic susceptibilities range from 0.007 to 0.091 (SI) - average of 0.034 (SI) for the mafic dykes (Raposo and Ernesto, 1995) and densities of 2.96 $\mathrm{g} / \mathrm{cm}^{3}$ considering Serra Geral Formation basalts. The alkaline complexes are presented with average magnetic susceptibilities of 0.08 (Alva-Valdivia and López-Loera, 2011) and densities of $3.22 \mathrm{~g} / \mathrm{cm}^{3}$ based on the Jacupiranga, Pariquera-Açu and Juquiá complexes (AlvaValdivia and López-Loera, 2011; Slavec et al., 2001). Shukowsky et al. (2003) reported densities ranging from $2.84 \mathrm{~g} / \mathrm{cm}^{3}$ to $3.06 \mathrm{~g} / \mathrm{cm}^{3}$ for the carbonatite rocks of Jacupiranga Complex.

The gamma-ray data have not displayed any anomalies, nor geomorphological features could determine a near surface intrusion spreading along an approximately flat area, half-covered by the sea (Fig. 2a). The magnetic and gravity ground data indicate anomalies in the same area, nevertheless (Ferreira et al., 2018). The anomalies can be associated to one or more intruded bodies, which intrusion process did not chemically interact significantly with the host rock, or that such evidences had been washed up by the Atlantic Ocean since its opening during the late Cretaceous.

The airborne magnetic field data revealed a reverse polarized anomaly for the southern hemisphere ranging from -1048 to $522 \mathrm{nT}$ (Fig. 3). The high amplitude reverse signature evidences an important remanent magnetization in the source body. Most of the common processing and modelling techniques for magnetic field data do not consider the presence of remanent magnetization dominating the signal. To overcome this condition, it was used the methodology for processing and modelling of Louro et al. (2017).

The lateral limits were estimated using the 3D Analytic Signal (Roest et al., 1992; Fig. 4a), displaying two areas of high contrasts of about $5.5 \mathrm{~km}$ in NW direction. The two zones could be interpreted as subparallel dykes, or as a single source with steep edges, both common in the PGA. The Analytic Signal also displayed NW-SE-oriented lineaments, possibly associated with mafic dykes. The phase of the analytic signal filtering (TILT; Miller and Singh, 1994) was applied on the total magnetic field to highlight the magnetic lineaments in the area. The lineaments displayed on the Analytic Signal map (Fig. 4a) were enhanced and traced (Fig. 4b), agreeing with the NW-SE trend of the PGA. The TILT revealed the extension of the lineaments and indicated that at least seven of them interfere in the magnetic anomaly of the Canoas site.

An inclination of $53^{\circ}$ and a declination of $215^{\circ}$ were estimated as total magnetization directions using the MaxiMin technique (Fedi et al., 1994). The reduction to the magnetic pole obtained in this process (Fig. 4c) is centered over the anomaly and display an analogue behavior to the Analytic Signal. 


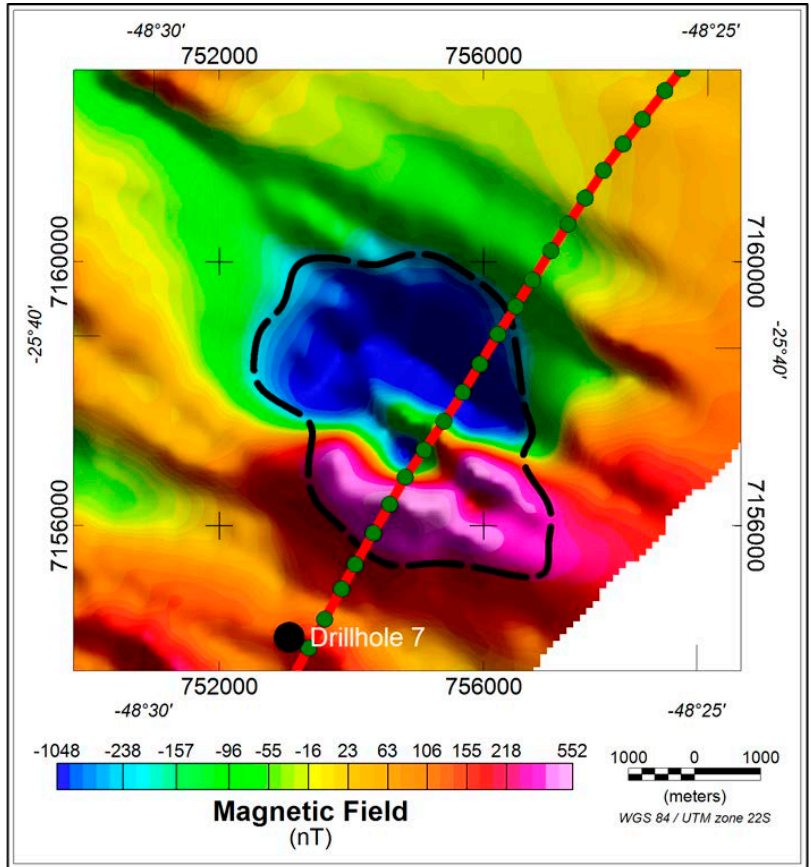

Figure 3 - Total magnetic field of the Canoas beach area. The dashed line indicates the area of the magnetic field anomaly, the red line shows the ground magnetic stations, and the green circles the gravity stations.

The reduced to the pole field allowed using the Euler Deconvolution (Reid et al., 1990) to investigate the depth to the top of the magnetic source.

The Euler Deconvolution was performed using the methodology of Florio et al. (2014) of upward continuing the magnetic field followed by the AN-EUL technique (Salem and Ravat, 2003) to suggest the best structural index for the subject. The AN-EUL technique was applied to upward continuated grids, with $50 \mathrm{~m}$ intervals from 0 to $800 \mathrm{~m}$. The structural index ranged from 0.5 to 1.0 , whereas the average depths varied from 200 to $300 \mathrm{~m}$. Respecting the rules suggested by Reid et al. (2014), the Euler Deconvolution was done using the structural index of 1.0 and variable window size from $330 \mathrm{~m}$ to $1500 \mathrm{~m}$. The estimated depths to the top of the anomalous source ranged from 18 to $457 \mathrm{~m}$ from the center to the most distal areas of the anomaly (Fig. 5).

The main magnetic anomaly displayed in the airborne magnetic field presented a dipolar feature about $5.6 \mathrm{~km}$ in the northeast-southwest direction, whereas the ground magnetic data show smaller anomalies, mostly nondipolar, with amplitudes up to $5700 \mathrm{nT}$ (Fig. 6a). These smaller anomalies had lengths from $275 \mathrm{~m}$ to $575 \mathrm{~m}$, coherent with elongated structures like the dykes from the PGA. The gravity data indicated a single anomaly of about $5 \mathrm{~km}$ in the direction of the ground survey (Fig. 6b), compatible with the length of the main anomaly observed in the airborne magnetic data. The composition of the three datasets allowed us to infer a geologic scenario where a major intrusion, possibly alkaline, would be cut across by younger or coeval mafic dykes.

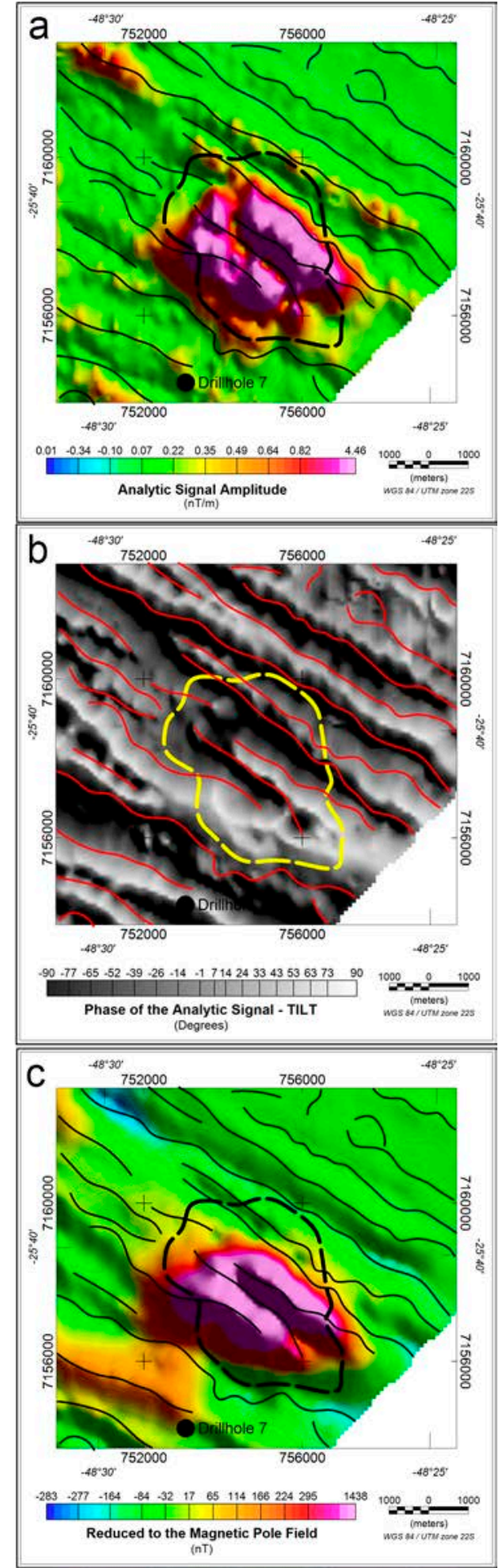

Figure 4 - Magnetic filtering results for the Canoas field: (a) 3-D Analytic Signal; (b) Phase of the Analytic Signal TILT; and (c) Reduced to the Magnetic Pole field, using inclination of $53^{\circ}$ and declination of $215^{\circ}$. The dashed line indicates the area of the magnetic field anomaly, whereas the solid lines show the magnetic lineaments observed using the TILT filtering. 


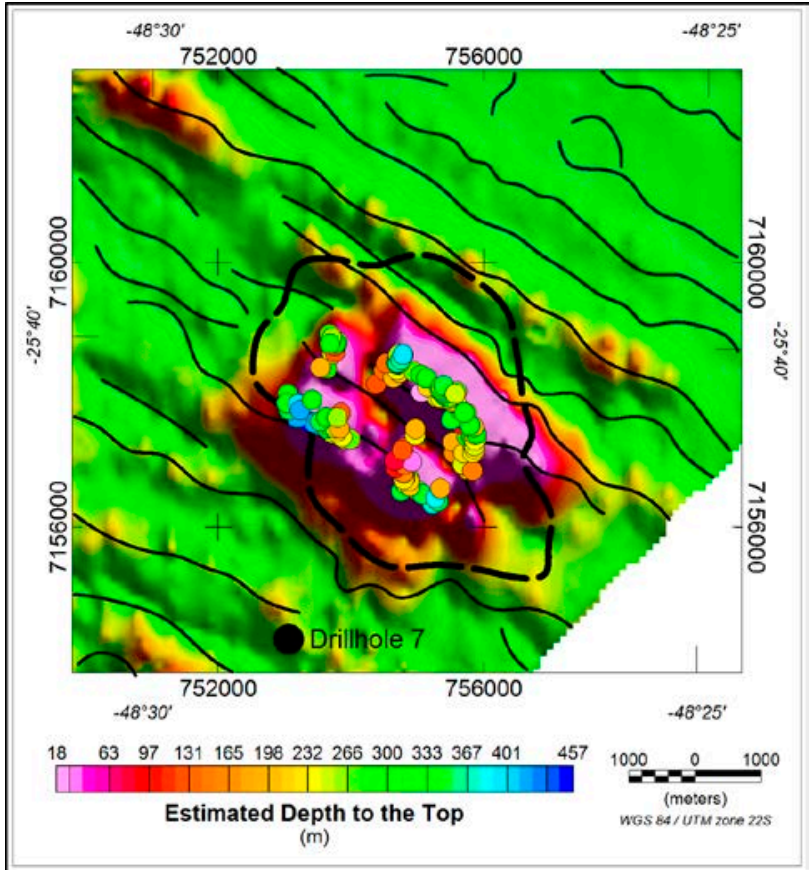

Figure 5 - Depths to the top estimated with the Euler Deconvolution using the structural index 1 and variable window sizes based on the magnetic field gradients. The dashed line indicates the area of the magnetic field anomaly, whereas the solid lines show the magnetic lineaments observed using the TILT filtering.

We composed a 3D model of the source of Canoas geophysical anomaly using all the available datasets. The model was constrained by the superficial lithologies, the lateral limits, depths and total magnetization direction specified by the magnetic filtering, induced magnetic field by the IGRF, magnetic susceptibilities and densities ranges observed in rocks present within the PGA. The joint gravity-magnetic modelling followed Louro et al. (2017) adaptation of the staged-inversion of Foss (2006).

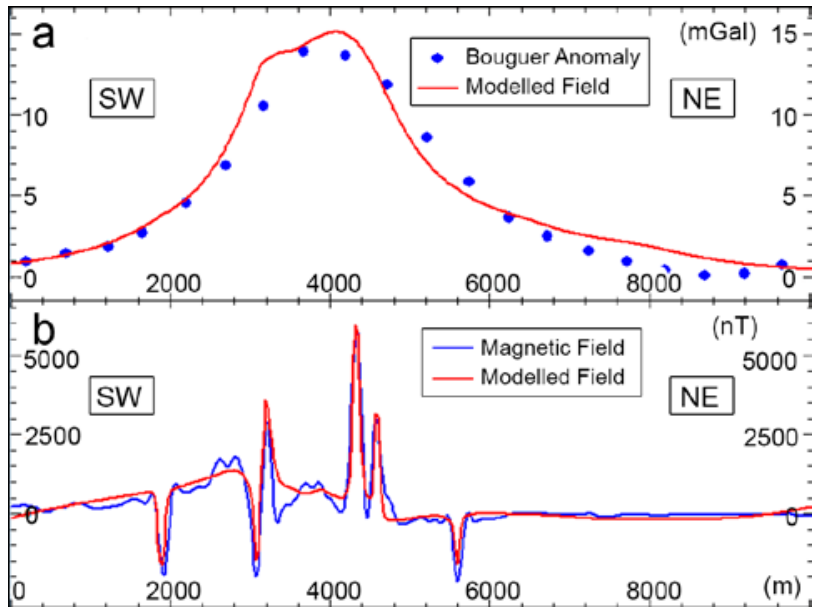

Figure 6 - (a) Ground Bouguer anomaly (blue circles) and gravity modelled field (red line); (b) Ground magnetic anomaly (blue line) and modelled field (red line).

The residuals between surveyed and modelled data were reduced to RMS errors smaller than $5 \%$ for all data used. Besides the similar residuals for the ground and airborne data models, considerably different high amplitude anomalies are seen in each of them. Both in airborne and ground data, localized peaks of field residuals could be found to significant amplitudes (Figs. 6 and 7). These peaks are possibly related to highly magnetized dykes that crosscut the source of the magnetic anomaly in the NW-SE direction (Fig. 4). The different sampling, height and direction of the ground and airborne magnetic surveys were interpreted as the cause for high amplitude punctual residuals.

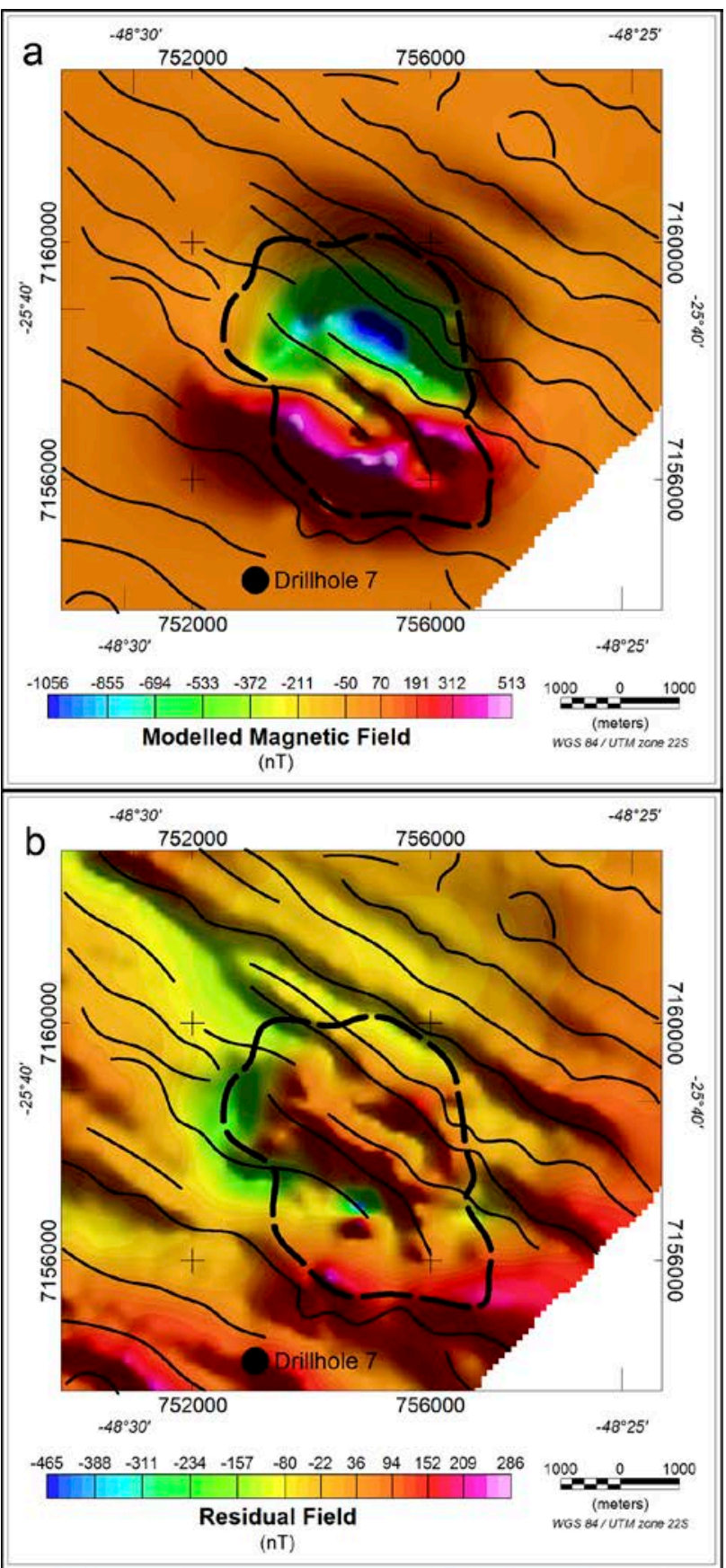

Figure 7 - (a) Canoas modelled magnetic field; and (b) Residual magnetic field. The dashed line indicates the area of the magnetic field anomaly, whereas the solid lines show the magnetic lineaments observed using the TILT filtering. 
The overall distribution of residuals was kept below 100 $\mathrm{nT}$ and $2.7 \mathrm{mGal}$ (Fig. 7b), indicating that the same model was enough to explain the magnetic data (airborne and ground collected) and the gravity data. The geophysical model proposed for the area of the Canoas anomaly is a composition of the main body, causing the reversepolarized anomaly, and a set of nine dyke-shaped bodies oriented in NW-SE direction (Fig. 8), according with the magnetic lineaments presented in Fig. 4. The main body was elongated in the direction of the lineaments, respecting the regional trend set by the PGA. Its shape is analogue to those seen in large alkaline complexes in south Brazil, e.g. Jacupiranga (Alva-Valdívia and LópesLoera, 2011), Tunas (Vasconcellos and Gomes, 1992), Banhadão and Itapirapuã (Gomes et al., 2018). In its largest axis, the model had c.a. $5.5 \mathrm{~km}$, whereas its smallest axis had about $3 \mathbf{~ k m}$. Its shallower horizons were fixed by the Euler Deconvolution results. The modelled dykes presented 60 to $200 \mathrm{~m}$ width, extending in NW-SE direction for up to $8 \mathrm{~km}$. These models had magnetization intensities up to $25 \mathrm{~A} / \mathrm{m}$, as seen in dykes of the PGA described by Raposo (1995) and Ussami et al. (1991).

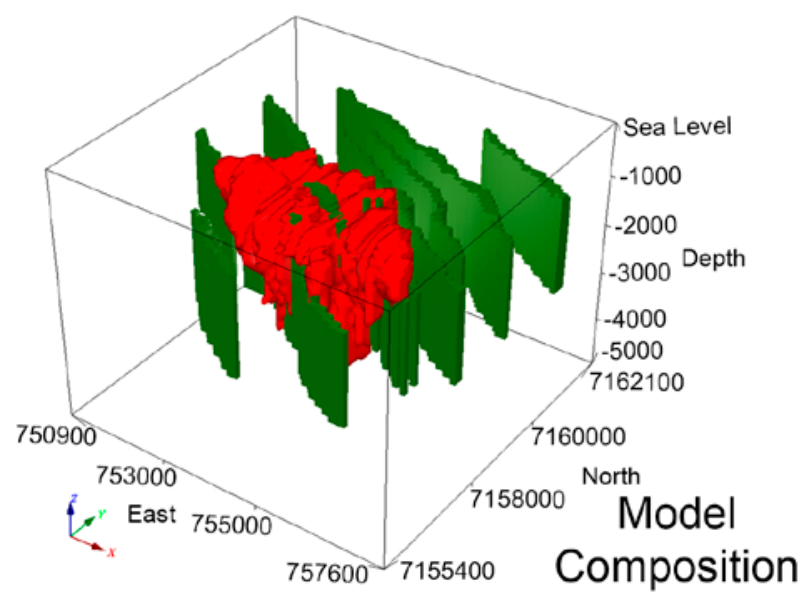

Figure 8 - Geophysical model for Canoas anomaly area indicating the alkaline body (red) and dykes (green).

\section{Conclusions}

In the southeastern PGA, between the São JerônimoCuriúva and Rio Alonzo lineaments, an anomaly appears in surveys for magnetic and gravity data. The Canoas anomaly has no outcropping geological expression or indirect expression in a nearby drillhole. The most frequent lithologies in the area that could cause magnetic and gravity anomalies are alkaline complexes and mafic dikes from the PGA.

We performed a linear southeast to NW-SE ground magnetic and gravity survey in 2006 that, along with airborne magnetic field data collected on 2009 and 2010, permitted an extensive analysis of the possible source for this anomaly. The magnetic anomaly seen in the airborne-collected data showed a reverse-polarized anomaly, whereas the ground data indicated several anomalies of small wavelength. The gravity field, although ground surveyed, presented an anomaly coherent with the airborne magnetic anomaly.
The source of the airborne magnetic and ground gravity anomalies was delimited as a NW-SE-oriented body of about $5.5 \mathrm{~km}$ in this direction, with its bulk intruded at approximately $200 \mathrm{~m}$ below the surface, getting to less than $20 \mathrm{~m}$ in its central portion. After modelled, this body had average density of $3.2 \mathrm{~g} / \mathrm{cm} 3$ and average magnetic susceptibility of 0.1 (S.I). The small wavelength anomalies obtained in the ground survey were modelled as bodies of up to $200 \mathrm{~m}$ wide of average magnetic susceptibilities of 0.05 (S.I.) and average densities of $3.1 \mathrm{~g} / \mathrm{cm} 3$. These bodies were interpreted as mafic dykes containing significant remanent magnetization, also common in the PGA.

The magnetic anomaly clearly indicated the presence of remanent magnetization, which was estimated in inclination $50^{\circ}$, declination $192^{\circ}$ and intensity of $4.8 \mathrm{~A} / \mathrm{m}$. This anomaly was qualitatively coherent with the magnetic expression of the $133 \mathrm{Ma}$ Juquiá/Morro do Serrote alkaline complex, about $170 \mathrm{~km}$ to northeast and still within the PGA area.

With more than half of its area below the Atlantic Ocean and city limits, the possible Canoas alkaline does not present a very promising exploratory target in a shortterm, especially compared with other alkaline outcropping complexes in the PGA. The knowledge and confirmation of the nature of the Canoas source, however, can represent new phosphate and Rare-Earth Elements reserves in south Brazil.

\section{Acknowledgments}

The authors thank to Geological Survey of Brazil (CPRM) for providing the aeromagnetic data. FJF Ferreira acknowledges the grant from National Council for Scientific and Technological Development (CNPq, Brazil), under contract 303826/2018-5.

\section{References}

Almeida, F.F.M., 1983. Relações tectônicas das rochas alcalinas mesozóicas da região meridional da Plataforma Sul-Americana. Revista Brasileira de Geociências, 13, 139-158.

Alva-Valdivia, L.M., López-Loera, H., 2011. A review of iron oxide transformations, rock magnetism and interpretation of magnetic anomalies: El Morro Mine (Brazil), a case study. Geofísica Internacional, 50(3), 341362.

Beccaluva, L., Barbieri, M., Born, H., Brotzu, P., Coltorti, M., Conte, A., Garbarino, C., Gomes, C.B., Macciotta, G., Morbidelli, L., Ruberti, E., Siena, F. \& Traversa, G., 1992. Fractional crystallization and liquid immiscibility processes in the alkaline-carbonatite complex of Juquiá (São Paulo, Brazil). Journal of Petrology 33, 1371-1404.

Born, H., 1971. Complexo alcalino de Juquiá. PhD Thesis, Instituto de Geociências, Universidade de São Paulo, São Paulo, 185 p.

Castro, L.G.; Ferreira, F.J.F; Angulo, R.J. 2008. Modelo gravimétrico-magnético do Gráben de Paranaguá-PR, Brasil. Revista Brasileira de Geofísica, v. 26, p. 273-292. 
CPRM, 2011. Projeto Aerogeofísico Paraná-Santa Catarina. Companhia de Pesquisa de Recursos Minerais (Geological Survey of Brazil). Relatório Final do Levantamento e Processamento dos Dados Magnetométricos e Gamaespectrométricos, v.1, 88p.

Fedi, M., Florio, G., Rapolla, A., 1994. A method to estimate the total magnetization direction from a distortion analysis of magnetic anomalies, Geophysical Prospecting, 42, 261-274, doi: 10.1111/j.13652478.1994.tb00209.x.

Ferreira, F.J.F., Szameitat, L.S.A., Castro, L.G., Silva, V.A.F., Weihermann, J.D. 2018. Magnetic data evidence of a likely new alkaline intrusion at Canoas beach, Ponta Grossa Arch Alkaline Province, southern Brazil. VIII Simpósio Brasileiro de Geofísica, Salinópolis, Pará. Sociedade Brasileira de Geofísica (SBGf) (CD-ROM).

Foss, C., 2006. Evaluation of Strategies to Manage Remanent Magnetization Effects in Magnetic Field Inversion, 76th Annual SEG International Meeting. SEG, New Orleans, 5 p., doi: 10.1190/1.2370410.

Gomes, C.B., Ruberti, E., Comin-Chiaramonti, P., Azzone, R.G., 2011. Alkaline magmatism in the Ponta Grossa Arch, SE Brazil: A review, Journal of South American Earth Sciences, 32(2), 152-168, doi: 10.1016/j.jsames.2011.05.003.

Gomes, C.B., Azzone, R.G., Ruberti, E., Vasconcelos, P.M., Sato, K., Rojas, G.E.E., 2018. New age determinations for the Banhadão and Itapirapuã complexes in the Ribeira Valley, southern Brazil. Brazilian Journal of Geology, 48(2), 403-414, doi: dx.doi.org/10.1590/2317-4889201820170094.

Lessa, G.C., Angulo, R.J., Giannini, P.C.F., Araujo, A.D., 2000. Stratigraphy and Holocene evolution of a regressive barrier in south Brazil. Marine Geology, 165(14), 87-108, doi:10.1016/s0025-3227(99)00130-9.

Louro, V.H.A., Cawood, P.A., Mantovani, M.S.M., Ribeiro, V.B., 2017. Tectonic insights of the southwest Amazon Craton from geophysical, geochemical and mineralogical data of Figueira Branca mafic-ultramafic suite, Brazil. Tectonophysics, 708, 96-107, doi: 10.1016/j.tecto.2017.04.025.

Marques, L.S., Ernesto, M., 2004. O magmatismo toleítico da Bacia do Paraná. In: Mantesso Neto, V., et al. (Eds.), (Org.) Geologia do continente Sul-Americano: evolução da obra de Fernando Flávio Marques de Almeida. Beca Produções Culturais, São Paulo, 245-263.

Miller, H.G., Singh, V., 1994. Potential field tilt - a new concept for location of potential field sources. Journal of Applied Geophysics, 32(2-3), 213-217, doi: 10.1016/0926-9851(94)90022-1.

Raposo, M.I.B. 1995. Episódio intrusivo no arco de Ponta Grossa, determinado através de um estudo paleomagnético. Revista Brasileira de Geociências 25(1), 3-19.

Raposo, M.I.B., Ernesto, M., 1995. Anisotropy of magnetic susceptibility in the Ponta Grossa dyke swarm (Brazil) and its relationship with magma flow direction.
Physics of the Earth and Planetary Interiors, 87(3-4), 183-196, doi: 10.1016/0031-9201(94)02970-M.

Reid, A. B., Allsop, J.M., Granser, H., Millett, A.J., Somerton, I.W., 1990. Magnetic interpretation in three dimensions using Euler deconvolution. Geophysics, 55, 80-91, doi: 10.1190/1.1442774.

Reid., A.B., Ebbing, J., Webb, S.J., 2014. Avoidable Euler Errors - the use and abuse of Euler deconvolution applied to potential fields. Geophysical Prospecting, 62, 1162-1168, doi: 10.1111/1365-2478.12119.

Riccomini, C., Velázquez, V.F., Gomes, C.B., 2005. Tectonic controls of the Mesozoic and Cenozoic alkaline magmatism in the central-southeastern Brazilian Platform. In: Comin-Chiaramonti, P., Gomes, C.B. (Eds.), Mesozoic to Cenozoic Alkaline Magmatism in the Brazilian Platform. Edusp/Fapesp, São Paulo, 31-55.

Roest, W.R., Verhoef, J., Pilkington, M., 1992. Magnetic interpretation using the 3-D analytic signal. Geophysics, 57, 116-125, doi: 10.1190/1.1443174.

Ruberti, E., Gomes, C.B., Comin-Chiaramonti, P., 2005. The alkaline magmatism from the Ponta Grossa Arch. In: Comin-Chiaramonti, P., Gomes, C.B. (Eds.), Mesozoic to Cenozoic Alkaline Magmatism in the Brazilian Platform. Edusp/Fapesp, São Paulo, 473-521.

Rugenski, A., Mantovani, M.S.M., Shukowsky, W., 2006. Investigação Gravimétrica do Complexo Alcalino de Ipanema, São Paulo, Brasil. Geologia USP Série Científica, 6(1), 13-27, doi: 10.5327/S1519874X2006000200002.

Salem, A., Ravat, D., 2003. A combined analytic signal and Euler method (AN-EUL) for automatic interpretation of magnetic data. Geophysics, 68(6), 1952-1961, doi: 10.1190/1.1635049.

Shukowsky, W., Mantovani, M. S. M., Bonás, T. B., 2003. Gravity prospecting for carbonatite at the Jacupiranga Alcaline Complex, Brazil. In: 8th International Congress of the Brazilian Geophysical Society, Rio de Janeiro, 4p.

Siga Júnior, O., Gomes, C., Sato, K., Passarelli, C., 2007. O maciço alcalino de Tunas, PR: novos dados geocronológicos. Geologia USP. Série Científica, 7(2), 71-80, doi: 10.25249/0375-7536.2001313365374.

Slavec, G.B., Mantovani, M.S.M., Shukowsky, W. 2001. Contribuição ao estudo do Complexo Alcalino de Juquiá. Revista Brasileira de Geociências, 31(2), 203-210.

Ussami, N. Kolinski, A., Raposo, M.I.B., Ferreira, F.J.F., Molina, E.C., Ernesto, M., 1991. Detectabilidade magnética do Arco de Ponta Grossa: Um estudo integrado de magnetometria terrestre/aérea e magnetismo de rocha. Revista Brasileira de Geociências, 21(4), 317-327.

Vasconcellos, E.M.G., Gomes, C.B., 1992. Caracterização petrográfica de brechas vulcânicas no Complexo Alcalino de Tunas, PR. Revista Brasileira de Geociências, 22(3), 269-274. 